\title{
A presença da indústria cultural no cenário musical em \\ Manaus na década de 1960
}

\section{Lucyanne Afonso Rosemara Staub de Barros Zago}

Resumo: A pesquisa faz a descrição e a análise da vida musical na cidade de Manaus na década de 1960. As inter-relações socioculturais existentes entre o jornal, o cinema e o rádio motivaram muitos jovens a realizar dublagens nos clubes da cidade, o que levou a organização do Festival de Dublagem nos anos de 1965 e 1966, mobilizou os clubes e artistas e, teve como patrocinadores o comércio, as gravadoras e a Loja de Disco Novidades que atuaram neste Festival com objetivos lucrativos. Entretanto, os artistas tinham conhecimento dos objetivos da indústria cultural em função do festival, mas também almejavam a sua fama e o seu reconhecimento.

Abstract: The research is the description and analysis of musical life in the city of Manaus in the 1960s Existing socio-cultural interrelations between the newspaper, cinema and radio prompted many young people to perform dubbing in the city's clubs, which led to organization of Dubbing Festival in the years 1965 and 1966, mobilized clubs and artists, and had as sponsors trade, record companies and Disk Shop News who acted in this Festival with lucrative goals. However, the artists were aware of the cultural industry goals due to the festival, but also longed for the fame and recognition.

\section{Introdução}

Esta pesquisa propõe-se a descrever e analisar como foi a vida musical na cidade de Manaus na década de 1960: o cinema e o rádio contribuíram para otimizar os espaços musicais e a ascensão dos artistas. Influência determinante nos gostos e comportamentos no cenário musical, tendo em vista um cenário nacional e global. 
A vida musical aqui abordada é representada pelas manifestações musicais que aconteceram nos espaços sociais da cidade, principalmente nos clubes e nas rádios, onde artistas emergiram e legitimaram uma forma de expressar musicalmente. Atrelado a isso, veremos como a indústria cultural legitimou o espaço cultural da cidade.

A década de 1960 foi um período em que o Brasil vivenciou um processo de profundas transformações sociais, políticas e culturais. Muitas modificações ocorreram na Música Popular Brasileira: novos estilos surgiram e com eles, cantores, compositores, grupos e conjuntos musicais foram transformando o cenário musical brasileiro e, assim, o cenário musical em Manaus, também se configurava.

Por detrás deste cenário musical está a indústria cultural presente no dia-a-dia do manauara: cinema, rádio, comércio de discos, jornais, que constantemente enfatizavam as regras ditadas pelas hegemonias econômicas e políticas do mundo.

Uma indústria cultural que definia o gosto, o comportamento, o que se ouvia, o que se tocava e, principalmente, o que se dublava nos clubes de Manaus.

A Dublagem foi uma manifestação musical produzida, inicialmente por ingenuidade e, em seguida, sendo direcionado pela indústria cultural presente em Manaus. Simbolizou comportamentos, hábitos e atitudes de jovens artistas e que também legitimou um espaço musical na cidade através dos clubes.

Trabalhamos com a hipótese de que a indústria cultural definiu os espaços, os gostos e os comportamentos neste período. Analisamos também, as mudanças que a dublagem trouxe para a emancipação de artistas e para a construção de saberes musicais na cidade. 


\section{Material e Método}

As análises desta pesquisa tiveram como referencial teórico a tríade crítica de Theodor Adorno, quanto à indústria cultural: a escolha, a divulgação e o efeito. Esta tríade será visualizada e analisada criticamente, através do cotidiano da vida social e musical da cidade de Manaus dos anos de 1960.

O gráfico a seguir, demonstra o fluxo da presente análise:

\section{A ESCOLHA}

\section{GRAVADORAS E LOJAS DE DISCO}
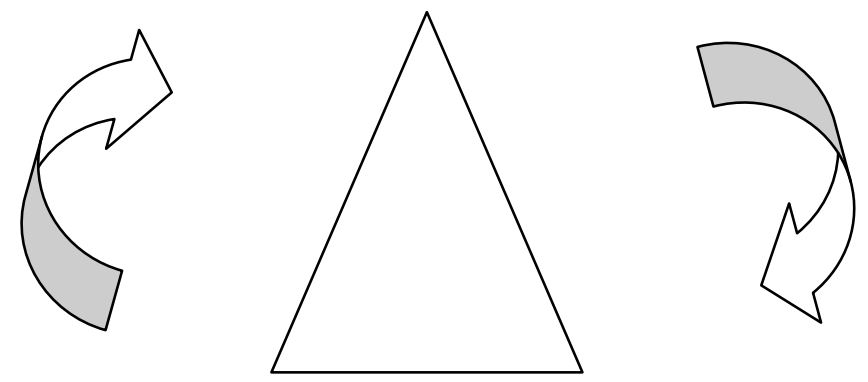

\section{O EFEITO}

\section{DUBLAGEM}

CINEMA

Festival de Dublagem

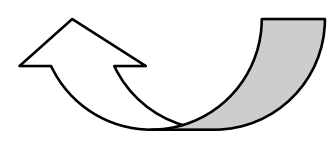

A DIVULGAÇÃO

O JORNAL, $O$

E O RÁDIO

Nesta pesquisa, a "escolha" é analisada, sob o ponto de vista das gravadoras e das lojas de discos. As gravadoras tinham a função de encaminhar os Lp's para as lojas de discos e para as rádios. As lojas de discos vendiam o que era encaminhado pelas gravadoras e cada uma tinha o seu representante que fazia este intercâmbio entre rádio e lojas.

A "divulgação" era realizada pelo jornal, pelo cinema e pelas emissoras de rádio. Cada um com seu papel definido: o jornal divulgava toda a programação do rádio e do cinema. $O$ rádio colocava no ar as 
canções de sucesso. E, o cinema ajudava na performance dos gestos, nas expressões corporais e faciais, na vestimenta.

Consequentemente, o "efeito" desta tríade da indústria cultural era concretizada pela dublagem, mais precisamente pelo Festival de Dublagem que culminou todo este processo: da gravadora até se chegar à escuta nas rádios de Manaus.

\section{Análise}

\section{Escolha - gravadoras e loja de discos}

As gravadoras e a loja de disco faziam a escolha do repertório a ser escutado e vendido. Todo processo passava pela rádio e o cinema culminando na escuta e na comercialização: a música é ouvida no rádio, assistida no cinema e comprada através do long play, se torna então um encontro entre o indivíduo e o mercado cultural que é promovido pelos grandes vetores de propaganda e publicidade aliados ao cinema e a rádio.

Houve uma interação muito grande entre cinema, rádio e a música comercializada: objeto de consumo e que traduz o glamour e o status que a indústria cultural dá ao ouvinte e aos artistas e que foi representado e dublado nos clubes mais sofisticados da cidade.

A venda de discos nos anos 60 em Manaus é bastante acentuada pelo grande número de festas na cidade com o aparelho $\mathrm{Hi}-\mathrm{Fi}$.

Esta comercialização era feita em poucos espaços do comércio local, haja vista que o comércio da Zona Franca estava abrindo portas para novos produtos do mercado nacional e internacional.

A primeira Loja que vendeu discos de cera em Manaus foi a Importadora Panamericana, onde é hoje, a Loja Belmiro's, na Avenida 7 de Setembro. 


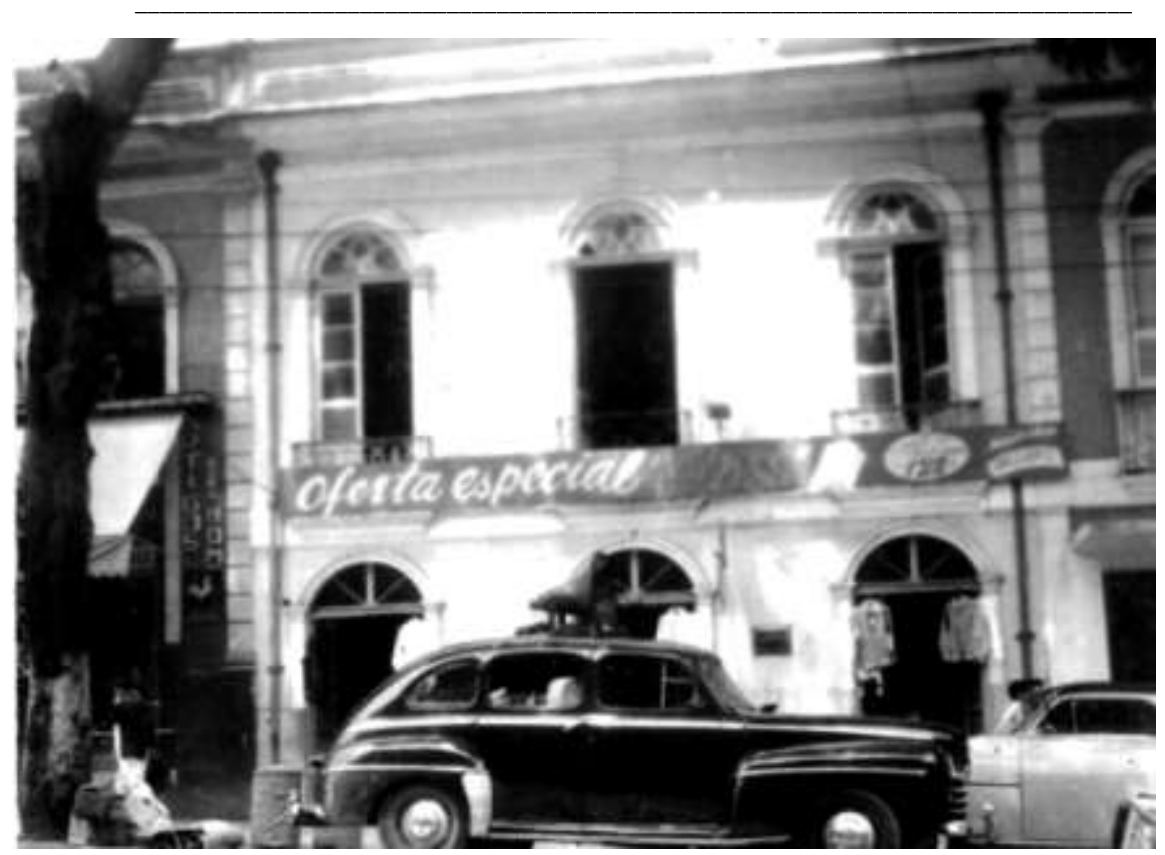

Figura 01: Importadora PanAmericana

Fonte: Coleção de fotos da família do entrevistado Fernando Antonio

Poucas eram as lojas que vendiam produtos musicais em Manaus, praticamente eram os Bazares e a Loja de discos. A principal e a mais famosa loja em Manaus era a Loja Novidades Discos, que começou "em 1959 na Eduardo Ribeiro, n.350 era parte do quarteirão que onde é hoje a Loja Riachuelo", relatou o Sr. Fernando Antonio da Silva, empresário e proprietário da Loja.

De acordo com o Sr. Fernando Antonio (2012) antes da Loja Novidades Discos já haviam dois bazares que vendiam discos e produtos musicais: eram o Bazar Brasileiro e o Bazar Esportivo.

Com o aumento de rádios e de grupos musicais proporcionou uma demanda maior de produtos para venda, foi assim que criou uma filial da Loja Novidades Discos chamada Novidades Eletrônicas para atender a este tipo de clientela: músicos, radialistas, tudo que correspondia a este tipo de mercado e que estava no auge em Manaus. 
A Loja Novidades Discos se firmou no mercado pelo simples fato de perceber a crescente demanda da indústria cultural: o progresso dos meios de comunicação, de propaganda e de diversão cultural. Assim, a Loja entrou nesse mundo do mercado e do consumo cultural, passou a ser conhecida pelas gravadoras e pelos artistas nacionais também: "Quem chegava pra se apresentar na cidade ia conhecer a Loja, deixava um autógrafo", relata o Sr. Fernando Antonio (2012). O vinil autografado ficava exposto na parede da Loja, era uma forma de divulgar tanto o artista quanto a Loja e, isso, só favorecia a venda e beneficiava a todos com a venda do disco: a Loja que vendia, as gravadoras que aumentavam seus rendimentos e os artistas que aumentavam seu público e imagem, atrelado a um ciclo de prazer e desejo.

Figura 02: Loja Novidades Discos (Sr. Fernando mostrando LP)

Fonte: Coleção de fotos da família do entrevistado Fernando Antonio

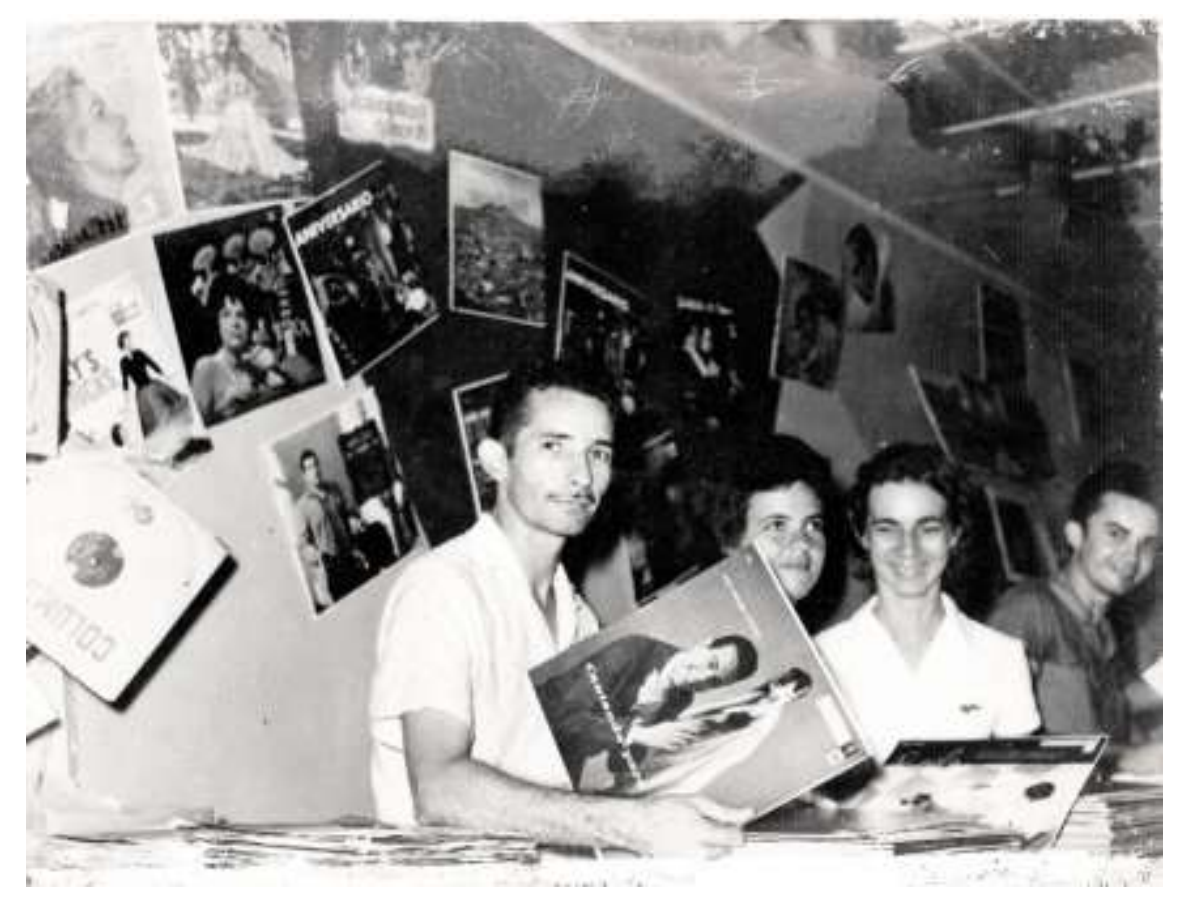

Este mercado não ficava restrito somente a venda $e$ comercialização dos Lp's nas lojas. O ciclo tinha que ser finalizado pela 
compra, ou seja, um eterno funcionar da máquina consumidora: da gravadora para as lojas; da gravadora para as rádios; e também da gravadora e da loja para a dublagem; das lojas, das rádios e das dublagens para a casa dos ouvintes. Esse ciclo era feito pelos representantes das gravadoras.

As gravadoras que distribuíam em Manaus eram: Phillips, Chantecler, RCA, CBS, Copacabana; cada uma dessas gravadoras tinha um representante para atender as Rádios em Manaus.

Os representantes das gravadoras nas emissoras eram: Joaquim Marinho (representante da gravadora Phillips), Ives José de Lima (representante da Chantecler), Paulo Soares (representante da gravadora Copacabana), Edson Paiva (gravadora CBS). Havia também duas outras gravadoras que foram citadas pelo Sr Fernando (2012), a firma Recife Irmãos Rosemblitz e a Cássia Muniz. Além da representação nas rádios tinham a função de pesquisar nas lojas de discos, em Manaus, os vinis mais vendidos, fazendo assim uma escala de um a dez dos discos mais vendidos para posterior divulgação dos menos comprados.

O processo da venda ocorria da seguinte maneira: as gravadoras repassavam o produto às lojas e eram divulgados pelos representantes nas rádios. Tudo o que era ouvido, era antecipadamente, escolhido para ser sucesso e vender. A divulgação era o negócio: quanto mais vendas, mais ouvida a música e mais sucesso ela fazia.

As músicas foram escolhidas e foram direcionadas para a venda. Um grupo de artistas em Manaus escutavam, ensaiavam e dublavam as canções que as gravadoras escolhiam.

A escolha da música era importante na dublagem, por isso tinham que estar atentos ao que era anunciado e executado no rádio, principalmente os grandes sucessos nacionais, dos cantores de rádio.

Esta comercialização era $o$ movimento das hegemonias representadas pela indústria cultural invadindo o cenário local: o ouvinte ouve aquilo que já vem pronto para fazer sucesso e proporcionar a venda do produto musical. 


\section{Divulgação: jornal, cinema e rádio}

Na tríade de Adorno (2011), a divulgação é um dos vértices dessa tríade que por analogia o jornal, o cinema e o rádio são os meios de comunicação da música dos anos 60 em Manaus.

Estes veículos da mass media não foram somente para levar a informação, haja vista que "a informação, sobretudo aos serviços das forças econômicas hegemônicas e ao serviço do Estado, é o grande regedor das ações que definem as novas realidades espaciais" conforme Santos (1999, p.226), mas foram os mediadores do conhecimento para os artistas locais.

Adorno (2011) relata que as músicas de sucesso praticamente foram impostas pela indústria cultural sem que o ouvinte tivesse a devida escolha.

A partir de 1965, houve uma mudança na forma de fazer Jornal, Rádio, Cinema e TV e, consequentemente, a programação e as edições foram modificadas, levando em consideração dois períodos: antes de 1965, um período de chegada, estabelecimento e crescimento das emissoras locais; e após 1965, quando os serviços de rádio e comunicação ficaram subordinados à chefia militar do gabinete do Governador do Estado.

\section{Jornal}

Os jornais foram fundamentais neste processo da divulgação das programações dos clubes, do rádio e do cinema. Eles facilitaram a informação, pois eram o meio mais acessível no período, chegando ao leitor as notícias sobre as festas nos clubes, os artistas famosos que iriam se apresentar, os programas musicais das rádios, além dos filmes nos cinemas, informando a hora, o dia e a motivação para o evento. 
As notas nos Jornais eram diversas sobre as programações nos clubes. Dentre elas destacamos os títulos das notícias relacionadas a boates, confraternizações, atrações.

As notícias eram variadas seja em relação à divulgação da programação cultural, com a presença de algum cantor ou, se referindo a um domingo de sol, ou seja, às "Manhas de Sol" realizadas nos clubes.

Pelas notícias impressas, podemos analisar que, nesta década, houve uma diversificação na programação destes clubes, levando em consideração a proposta cultural de cada clube e o cenário histórico que desenvolveu neste processo.

Temos então uma divisão no formato da apresentação da divulgação nos jornais, entendendo também como uma divisão no desenvolvimento do espaço musical em Manaus:

a) De 1960 a 1964 a programação se refere às festas carnavalescas, banho de sol, festas folclóricas, boates, show musical, a programação não especifica o artista ou indica vários artistas, assim como os ritmos dançantes como Hi-Fi (Alta Fidelidade), Tertúlias dançantes ou no ritmo das Orquestras que eram formadas por no máximo 10 pessoas.

b) A partir de 1964, a nomenclatura Orquestras é substituída pela nomenclatura Conjuntos Musicais e a divulgação nos jornais enfatizava a trajetória do cantor que foi construindo uma carreira, elaborando seu estilo musical.

Os jornais foram grandes parceiros das rádios, eram através deles que se divulgava a rádio, conhecia a programação, os programas musicais mais famosos, o casting de artistas das emissoras, os eventos promovidos e divulgavam constantemente os artistas que iriam se apresentar nos programas de auditório, repetindo por vários dias a notícia sobre determinado evento e sua importância para a cidade. Divulgavam toda a programação de filmes dos cinemas de Manaus e, as apresentações que eram realizadas no palco, como os festejos e shows de cantores. 
As programações eram todas veiculadas nos jornais da cidade, sendo assim, o jornal exerceu uma grande importância para a audiência dos programas de rádio e dos filmes. Esta relação entre as medias facilitou a entrada do gosto americano, influenciando diretamente na vida musical na cidade.

\section{Cinema}

O cinema esteve muito presente como atividade cultural na cidade de Manaus. Ele congregava os festejos de aniversários, servia de ponto de encontro entre jovens para se divertir.

O que se via no cinema eram os filmes musicais hollywoodianos; muitos jovens que estavam aprendendo a tocar um instrumento viam sessões várias vezes para aprender os acordes da música ou mesmo para imitar os ídolos nos clubes e nas festas da cidade.

Segundo Morin (1989, p. 47), a cidade de Hollywood, onde eram encenados os grandes filmes musicais, se transformou na cidade dos sonhos reais.

Em Manaus, essa vida real mítica se desdobrará no artista querer ser o ídolo do cinema, querer representar tal e qual o cantor nos clubes da cidade, uma forma de viver um sonho hollywoodiano.

Adorno (2002, p.15) ressalta como era a reprodução exata do mundo nas telas do cinema. Por outro lado, Tinhorão (1997, p.57) destaca a presença desse bombardeamento do cinema e dos discos como um modelo americano de forma de vida:

Para Benjamin (1969, p. 230) o cinema enriqueceu nossa atenção e revelou o mundo: "O que caracteriza o cinema não é apenas a maneira pela qual o homem se apresenta ao aparelho, mas também o modo pelo qual ele figura na representação - devido a este aparelho - o mundo que o cerca."

A vida americana entrou nas casas das cidades através do cinema, do rádio e dos discos: definindo e influenciando os espaços 
locais. Manaus, não foi diferente, a cidade também entrou no clima dos filmes americanos e isso chamava a atenção dos jovens artistas que iam ao cinema aprender como o artista se comportava em palco, seus jeitos e vestimentas, enfim, foi uma cartilha em formato de tela.

A radialista Jerusa Santos (2012), em entrevista concedida, relata que nesse período havia muito filme musical e relembra alguns grupos que participavam de filmes musicais como The Platters e a Orquestra Glenn Miller.

Benjamin (1969, p.224) retrata como o cinema é um grande reprodutor da indústria cultural: O cinema constrói artificialmente, fora do estúdio, a 'personalidade' do ator: o culto da 'estrela', que favorece o capitalismo dos produtores cinematográficos, protege esta magia da personalidade que há muito já está reduzida ao encanto podre de seu valor mercantil.

Uma indústria cultural bastante presente no fazer artístico de nossa cidade. Benjamin retrata bem esta questão que o cinema constrói uma imagem não só do artista, mas do mundo, por meio de valores do mercado que estabelecem padrões de vida.

Segundo Morin (1989, p. 67) a vida imaginária da tela é o produto de uma necessidade real do homem, o homem se projeta a si mesmo para representar seus desejos, angústias e sonhos: "O homem sempre projetou em imagens seus desejos e temores. E projetou sempre na sua própria imagem - em seu duplo - a necessidade de superar a si mesmo na vida e na morte".

É importante frisar, que o cinema em Manaus, especificamente esta atividade que os artistas faziam em ir ao cinema e assistir várias sessões para aprender, criou-se uma rotina por eles e foi fundamental para desenvolver os gestos e vestimentas dos ídolos que posteriormente seriam imitados.

Uma vida real mítica de representar o sonho de ser ídolo, assim como os artistas do cinema que se transformaram em estrelas ou deuses. 
Consequentemente as dublagens em Manaus foram o retrato das performances musicais do cinema, sem a imagem, não teriam referência para reproduzir e assim ganhar status de artista na cidade.

\section{Radio}

A década de 1960 marca um início de uma nova era das telecomunicações: as emissoras de rádio já estavam atuando, como as Rádios Baré, Difusora, Tropical, que hoje é a Rádio Cidade.

Inicia então o que Bloom (1991, p.36) chama de Influência Poética, ou seja, os cânones, os ecos ou os movimentos que vão acontecer na Música Popular em Manaus, "o contexto em que se passa o ciclo vital, será compelido a examinar as relações entre poetas de uma só vez como casos equiparáveis ao que Freud denomina romance familiar".

O que ouço é o rock americano, o que vejo no cinema são os musicais de Hollywood e assim por diante.

Neste cenário global é que a cidade de Manaus vai delinear a vida musical e vai legitimar espaços e artistas.

Todas essas influências, tanto os programas das emissoras quanto a vinda de cantores nacionais para Manaus, possibilitou que os artistas passassem a ter contato e experiências com outras situações e espaços, modificando sua forma de fazer música para fazer parte desse espaço global hegemônico.

Adorno (1996, p.74) relata que esses espaços são comandados pelos componentes da indústria cultural.

Dessa forma, o rádio, colaborou para o desenvolvimento da produção local e se tornou um importante ponto de intersecção entre os espaços global e local.

Em Manaus, segundo Adelson Santos (2011) as programações das emissoras seguiram um padrão da Rádio Nacional: o rádio era o meio onde se escutava, conhecia e aprendia sobre Música Popular: 
Os artistas, a seguir, foram as atrações na cidade de Manaus, artistas que se conheciam somente pela voz quando se ouvia nas Rádios e posteriormente pelo Cinema. Foram os "professores de música" dessa geração de artistas em Manaus e as vozes das dublagens nos clubes tocados pelos LP's, entre 1964 a 1965: Angela Maria, Jorge Bem, Jerry Adriani, Djalma Lucio, Otacílio Amaral, Cauby Peixoto, Altemar Dutra, Roberto Carlos, Francisco Carlos, Wanderleia, Jairo Aguiar, Dalva e Helinho, Tereza Khury; e de 1967 em diante: Reginaldo Rossi, Roberto Carlos, Erasmo Carlos, Wanderleia, Conjunto Expressão, Jair Rodrigues, Lindomar Castilho, Maria Godoy.

Os artistas da cidade não tinham condições de ter acesso a grandes centros urbanos pela distância, pela insuficiência do meio de transporte aéreo e pelas condições financeiras e, principalmente, porque não tinham técnica suficiente para tal empreendimento artístico.

Como diz Santos (2001, p. 24) "o desenvolvimento da história vai de par com o desenvolvimento das técnicas". As técnicas referentes ao cenário musical dizem respeito a instrumentos eletrônicos, a escolas específicas para o aprendizado do violão, do teclado, o que era incipiente nesta década, visto somente as escolas de música para instrumentos como violino e piano, onde as principais eram a Escola de Música Ivete Ibiapina e a Escola de Música Ana Carolina.

O aprendizado era puramente autodidata, pois não haviam escolas de música específicas para instrumentos mais populares como violão, o canto, as guitarras, bateria, como hoje existem várias, assim como não tinham muitos compositores, podemos citar Maranhão, Aureo Nonato, Domingos Lima.

Podemos por em destaque o Conservatório de Música Joaquim Franco, uma instituição pública de ensino musical que foi criado em 1965, em Manaus. Com isso, formaria músicos profissionais e contribuiria para o desenvolvimento cultural na cidade. 
Desta forma, o rádio foi o principal veículo de aprendizado das músicas que eram tocadas na Rádio Nacional e nas rádios local, podendo o cantor ouvir as músicas de sucesso e os famosos cantores do Brasil.

A grande motivadora dessa geração de artistas foi o rádio, o cinema complementou visualmente o que se escutava. Era o ouvir, escrever e aprender a música para cantar, e ou, ouvir e aprender a música para tocar, como Noval Benaion relata em entrevista: "tinha que tirar a música de ouvido!" (2011).

Foi assim que essa geração musical foi se formando e consolidando um cenário musical na cidade.

A Rádio Difusora e a Rádio Baré foram as principais que realizavam este tipo de eventos e também os programas de auditório ao vivo. É importante salientar que, os programas de auditórios nas rádios cariocas já aconteciam desde a década de 1930, comercializando o samba-canção.

As emissoras Difusora e Baré tinham também eventos externos que traziam artistas nacionais para apresentar na cidade. A Rádio Difusora era a Festa da Mocidade, e a Rádio Baré a Maloca dos Barés.

De acordo com Jerusa Santos (2012) a Rádio Baré tinha mais facilidade em trazer artistas por estar ligada a Rádio Tupi do Rio de Janeiro, por isso a Maloca dos Barés era muito frequentada e apreciada pela população.

Enfim, assim como os clubes delinearam esse fazer artístico, a rádio também foi um dos espaços socioculturais que delineou o cenário da Música Popular em Manaus, se tornando fundamental para a determinação do gosto musical do público e da consolidação de estilos musicais.

A dublagem e covers de artistas nacionais e internacionais foi uma produção musical que a rádio estimulou no decorrer do processo. $\mathrm{O}$ artista se torna um produto daquilo que lhe é imposto pela rádio e pelo cinema. 
Uma indústria cultural totalmente presente na realidade musical manauara, mas ainda uma produção incipiente, embora suas influências todas tenham sido na indústria cultural que estava bastante presente: o rádio, o cinema.

\section{Efeito: Festival de Dublagem}

Os efeitos é o último vértice da tríade de Adorno (2011), sendo este o resultado da escolha e da divulgação. Iremos abordar como se deu o efeito da escolha e da divulgação nos espaços musicais da cidade e que resultaram no Festival de Dublagem.

Muitas transformações ocorreram nesse espaço cultural, no espaço musical da cidade que se trata de lugares, de música popular. Em que lugares a sociedade se divertia em Manaus? Que músicas ouviam e dançavam? O que se fazia de Música Popular em Manaus? Quais a características musicais dessa música e dessa geração de músicos da década de 1960 ?

Adorno (2011, p 243) relata que a vida musical é todo complexo de circulação de atividade artística numa cidade.

Podemos verificar que Manaus ficou mais movimentada a partir da segunda metade da década de 1960, apesar de ter tido, nesse período, um grande impacto de desenvolvimento, o comércio da Zona Franca. As manifestações culturais foram aos poucos se moldando a esta nova forma de crescimento, um processo longo de estruturação cultural.

Como relata Milton Santos (2001, p. 106) "os lugares são, pois, o mundo que eles reproduzem de modos específicos, individuais, diversos. Eles são singulares, mas também são globais, manifestações da totalidade do mundo, da qual são formas particulares".

Assim, Manaus passaria a ser uma cidade global, vai sendo culturalmente transformada aos modelos europeus de valorização da 
cultura, enfim, na Europa onde o turismo é valorizado deixando bilhões nessa atividade.

Uma das principais formas para se compreender uma cidade são suas manifestações artísticas. Adorno (2011, p.257) retrata que os meios de comunicação de massa participam ativamente da vida musical na cidade e apenas por meio deles se amplia o conhecimento musical.

Esse espaço sociocultural e a indústria cultural definem o espaço da música na cidade de Manaus.

No Teatro Amazonas, por exemplo, esse espaço apresentava concertos de artistas internacionais e dos artistas da cidade, no caso os pianistas que tinham um reconhecimento nacional e que levava o nome do Estado aos outros cantos do país como exemplo, Arnaldo Rebello.

Estes artistas traziam culturas diferentes e estabeleciam vínculo com a cidade, haja vista, seus retornos constantes a Manaus servindo a uma determinada classe da sociedade manauara, influenciando na formação de pianistas das escolas de música da cidade voltadas para o ensino do piano, violino, como o tenor Pepes Del Palucci e a soprano Blanca Bouças.

Os cantores da cidade, que eram intitulados nos jornais e apresentados ao público como "artistas da nossa emissora", suas participações no Teatro Amazonas estavam atreladas às programações em homenagens às autoridades políticas promovidas pelas rádios.

Isso mostra como se organizou o espaço musical em Manaus: de um lado uma música clássica para um determinado público e espaço e, de outro, um espaço musical popular ligado a indústria cultural e ao Governo.

Os artistas estavam praticamente atrelados a uma emissora e conforme a sua programação, ou seja, uma festa ao ar livre ou mesmo uma homenagem às personalidades políticas, o artista fazia parte dessa programação. 
Um cotidiano obediente e disciplinado que era repassado pelo comportamento dos artistas e dos meios de comunicação.

Mozart, para ter reconhecimento diante da sociedade, tinha que se vestir também de nobre, gesticular como nobre e fazer música para o gosto musical da nobreza. Ou seja, a corte imperial definia um formato de música a ser composta, ouvida e tocada. Para se estabelecer neste ambiente e ter reconhecimento pelo seu talento, Mozart tinha que adaptar-se as hegemonias de seu tempo.

Em Manaus, esses reconhecimentos vão se dar nos clubes e nas rádios, que eram os espaços em que os artistas tinham para serem reconhecidos tendo como suporte a indústria cultural. Morin (1977, p.09) relata que iniciou na década de 1960 "uma transformação na infraestrutura cultural da nossa sociedade".

Os clubes reuniam jovens e famílias para prestigiar os eventos fechados, ou seja, nem toda a população de Manaus tinha o privilégio de entrar nos clubes para brincar um carnaval nos salões requintados.

É importante frisar que as festas eram regadas ao som das músicas que as gravadoras escolhiam para serem tocadas nas rádios e isso virava sucesso e diversão nas festas dos clubes.

Noval Benaion (2011), citando os ritmos mais presentes nas festas dos clubes: Todos: Samba, bossa nova, jazz, rock, ié ié ié (uma evocação tupiniquim do rock dos Beatles, "She loves you yeah, yeah"). la de Elvis, Beatles, Rolling Stones, I Dik Dik, entre alguns estrangeiros, Renato e Seus Blue Caps, Roberto e Erasmo Carlos, Tim Maia, Elis Regina, Jair Rodrigues, só para citar alguns.

O que se toca nestas festas são as músicas de entretenimento que a própria indústria cultural define que serão ouvidas.

Adorno (2011, p.120) relata sobre a música de entretenimento que é a mais consumida em termos de indústria cultural e são estas músicas que são tocadas nos clubes, vendidas como long play e reproduzidas na vida musical da cidade: "não é a toa que a música 
consumida preferencialmente é aquela relativa à esfera da música de entretenimento, completamente afinada com o tom do que é divertido".

Podemos verificar estas músicas de entretenimento na programação apresentada pelos clubes e o estilo dos cantores que vinham a Manaus. Esta programação sofreu alterações a partir de 1964 por questões que foram fundamentais para este novo cenário que se formava.

Esta mudança de programação não se deu por mero acaso, as hegemonias estavam atuando paralelamente a esta crescente mudança de programação musical que ocorria na cidade de Manaus.

E a motivação entre os jovens que iam se divertir nos clubes a partir dessa mudança de programação foi a dublagem: uma forma de ser artista e ter um certo status na cidade e também de querer ser o ídolo a qual passou imitar.

A partir desse crescimento de dublagens nos clubes da cidade, revelou um festival que agitou a cidade e permitiu que o comércio, as rádios e as gravadoras fossem as bases dessa manifestação musical em Manaus.

\section{Do divertimento ao consumo musical}

Segundo Adorno (2002, p.30) a indústria cultural é mediada pelo entretenimento e pela diversão. O Festival de Dublagem iniciou a partir de um divertimento, mas abriu caminhos para o profissionalismo de um grupo de artistas locais, nas décadas posteriores.

É fato que a indústria cultural exerceu grande influência e poder para que se chegasse a realizar um Festival de Dublagem que criou itens e critérios de concorrência em imitação ao que estava sendo mostrado na vida musical em Manaus. 
As rádios, o cinema, o comércio local, principalmente as principais lojas de discos Novidades e a gravadora Phillips possibilitaram essas mudanças no cenário musical.

Com a imitação de cantores no Luso Sporting Club feita pelo grupo Cly Baby Show por diversão, é que iniciou a inserção das gravadoras e da loja para mediatizar esta imitação.

O Sr. Fernando Antonio (2012), dono da Loja Novidades Discos, frequentador do Luso Sporting Club, começou a investir no Cly Baby Show. Segundo Delfim de Sá (2012) o Sr. Fernando mandou fazer guitarras iguais as originais, mas não tinham som, eram cópias idênticas.

Não era somente um investimento para ajudar um grupo na sua performance artística, o investimento era para divulgar a Loja e trazer lucros, pois as dublagens nos clubes favorecia a venda dos Lp's nas lojas de discos de Manaus pelos ouvintes ou pelos próprios artistas que dublavam.

O grupo não tinha dinheiro para comprar os vinis e emprestava do Sr. Fernando, mas quando a música era dublada no clube, a venda dos vinis aumentava na Loja Novidades Discos, foi o único período que a Loja foi divulgada.

Delfim de Sá (2012) relata que o grupo sabia que havia uma contrapartida entre o investimento e os negócios da Loja e das gravadoras.

Segundo Adorno (2011, p.117) a sociedade é dominada pelo princípio da troca, onde as ideologias se entrelaçam.

Da mesma forma, podemos verificar que há um princípio de troca entre o grupo Cly Baby Show, as gravadoras e a Loja. Como o grupo era o mais desprovido de função pelas próprias condições econômicas e sociais, tudo uniu o útil ao agradável: as ideologias de ambos os lados se entrelaçaram em interesses particulares de mercado e de fama.

A partir dessas dublagens feitas pelo Grupo Cly Baby Show virou moda nos clubes, então cada clube tinha na programação dublagem. 
Os clubes de Manaus passaram a colocar nas suas programações as dublagens que eram feitas pelos jovens que participavam daquele determinado clube, logo a cidade fervia dublagem ao som dos Beatles, Elvis Presley, Cauby Peixoto, Jair Rodrigues, Elsa Soares, Elis Regina e muito outros sucessos da época.

Ser socialmente reconhecimento era o propósito dos participantes, ser artista sério, isto significava um certo status ao que dublava no clube: ser reconhecido como o dublador de Roberto Carlos, ou Jair Rodrigues e Elis Regina, do Billy ou Elizeth Cardoso e Suely Campelo.

Mas para chegar ao festival em si, é claro que motivações ocorreram na cidade. Os festivais não aconteceram somente para divulgar as Lojas, a venda de vinis, mas também comemorar os festejos de aniversário da Rádio Baré, principal divulgadora e promotora do festival.

Um festival que se tornou uma febre: isso importava muito para o comércio local, que de certa forma impulsionou uma demanda maior de compra de discos e também de instrumentos musicais.

O Sr. Fernando Antonio (2012) foi quem comunicou a Phillips, através do representante de Manaus Joaquim Marinho, sobre o sucesso da dublagem e resolveram fazer o festival.

Quanto ao repertório musical do festival, não era escolhido pelo grupo ou pelas categorias individuais que iriam cantar, e sim, pelas gravadoras e pela Loja Novidades Discos.

Não somente a escolha do repertório era previamente feita pelas gravadoras, mas toda a indumentária era de acordo com o que viam no cinema e nas revistas.

De acordo com Delfim de Sá (2012) os participantes não tinham recursos, então toda a produção das roupas foi patrocinada pelas Novidades Disco e a gravadora Phillips: "do terno bem alto a encomenda das botas, tudo copiado das revistas e do cinema." 
O que estava na moda e fazendo grande sucesso tanto nas revistas e nos musicais dos cinemas desse período eram os Beatles. Logo, a escolha da indumentária da "categoria grupo" era feita pelos próprios participantes que, ao mesmo tempo, definia sua roupa de acordo com o repertório que era passado pelas gravadoras, sendo o patrocínio do figurino da gravadora Phillips e da Loja Novidades Discos.

Ao apresentar no Festival de Dublagem os artistas queriam somente a fama. Imitar os gestos, gesticular com o corpo e com a boca, e o figurino igual ao artista que a gravadora encomendava para dublar, significava ser artista, ter popularidade na cidade e, principalmente, alcançar o sucesso que tanto almejavam com a dublagem: querer ser o próprio artista que imitava.

O Sr. Fernando Antonio (2012) relatou que nenhum "participante ganhou cachê nenhum, foi pra ganhar fama".

Delfim de Sá (2012) comentou que tudo o que fizeram, embora sabendo das relações que o festival tinha com o comércio e as gravadoras, tudo foi por amor ao que faziam.

A premiação visava premiar os melhores artistas que eram referências na dublagem, sendo reconhecidos como artistas.

A maior influência para a existência desta dublagem em Manaus foi o cinema que era muito presente. Os jovens que começavam a aprender as músicas iam várias vezes ao cinema; era uma possibilidade de aprender, principalmente porque ajudava a ver as performances dos artistas, os figurinos, as características, a forma de tocar e cantar, etc., pois nesse período iniciaram os grandes musicais de Hollywood, os musicais nacionais, e os conjuntos musicais e seus cantores estavam presentes nestes filmes.

Os Festivais de Dublagem foram praticamente um amadorismo ou uma releitura dos filmes que eram vistos em Manaus, e a maioria era de filmes musicais internacionais produzidos em Hollywood, como os filmes que tinham Elvis Presley, que era um dos mais considerados nomes em 
filmes musicais. Como exemplo, os citados na dissertação de Aguiar (2000): "O Gordo e o Magro", os filmes de "Carlitos", "O Guarda Vingador", "Aranha Negra", "Teus olhos castanhos", os filmes de Alfred Hitchcock.

A tela do cinema, a voz que soa brilhantemente, na rádio e no disco confundem com a realidade, a imitação justamente era a reprodução desse mundo das telas, do sonho americano.

Adorno (2002) relata esse sonho americano reproduzido nas telas e sendo imitado nos espaços da cidade: "toda voz de tenor soa exatamente como um disco de Caruso, e os rostos das garotas do Texas naturalmente se assemelham aos modelos segundo os quais seriam classificadas em Hollywood" (p.35).

Desta forma, essa imitação dos ídolos corresponde apenas à abstração desse modelo de vida americana, não houve uma emancipação destes artistas em substituir o que já estava exposto nos meios de comunicação por outra atividade.

Santos (1991, p.116) cita Jean Brunhes em relação a diferentes fenômenos que se apresentam no decorrer do tempo e no mesmo espaço, acrescenta Branhes que o "cenário geográfico que permanece o mesmo, mas os homens que nele habitam passam por necessidades crescentes, mutáveis e crescentemente complexas".

O cenário geográfico de Manaus continuou o mesmo, mas os homens, referindo-se aos artistas da música, estavam em constante e crescente modificação artística e musical, haja vista, que não houve mais Festival de Dublagem, foram somente dois eventos, em 1965 e 1966.

\section{Conclusão}

Manaus, na década de 1960, foi uma cidade em desenvolvimento econômico, social, político e cultural. Projetos começaram a ser 
elaborados para seu crescimento e consequentemente houve um aumento de atividades culturais na cidade.

Apesar da distância dos grandes centros econômicos e culturais do Brasil, Manaus tinha uma vida social e musical intensa, recebeu influencias externas para realizar seu modo de fazer cultura.

O espaço da Música Popular se concentrou nos grandes clubes da cidade e, é nesse espaço que definiu a trajetória dos artistas e, ao mesmo tempo, houve mais difusão cultural na cidade.

Os clubes tiveram uma função de unificar a juventude e promover o consumo cultural organizado pela indústria cultural. Desta forma, podemos entender que os clubes exerceram um fator preponderante para a circulação do produto de consumo, haja vista as rádios e os jornais ajudaram a consolidar o espaço cultural na cidade.

As emissoras de rádio em Manaus (Difusora, Baré e Rio Mar), por sua vez, se tornaram uma escola de música para os artistas, devido à falta de escolas especializadas, para a área popular: canto, violão, guitarra e bateria. Os artistas ouviam na rádio a música e aprendiam tanto a cantar quanto a tocar.

O cinema também foi um meio para o aprendizado das canções, mas o cinema tinha algo a mais: a imagem, o que permitiu ao artista, perceber o gestos, o figurino, a performance de seu ídolo no cinema, como os filmes musicais que constantemente eram exibidos com a participação Elvis Presley e The Beatles.

A presença dos produtos de consumo da indústria cultural foi essencial para a formação do artista local, principalmente para aqueles que faziam dublagens nos clubes da cidade. Ou seja, era essencial ouvir a música na rádio ou do LP comprado para aprender as canções e ir ao cinema para aprender os gestos dos cantores.

Essa juventude da década de 1960 moldou seu gosto ao som da música americana, dos filmes musicais, do penteado diferente, das 
roupas descoladas, criou hábitos e costumes que foram repassados pela indústria cultural, a indústria do consumo.

O embricamento da indústria cultural em Manaus, o rádio, o jornal e o cinema e, respectivamente os seus produtos, facilitaram a entrada dos produtos de consumo da época, neste caso, a música americanizada, os filmes musicais, as vozes do Brasil e do mundo estavam presentes na escuta dos jovens artistas. O cânone da indústria cultural se estabeleceu em Manaus, pois um dependia do outro para a divulgação do produto e para movimentar a indústria do consumo local.

Manaus teve a influencia dos produtos de consumo da indústria cultural presente no espaço social e musical da cidade: $O$ artista ouvia o rádio para aprender a canção, ia ao cinema para aprender os gestos, comprava o disco para ter em sua posse, além de investir na compra do instrumento musical, o qual estava mais acessível, como a bateria dos Beatles.

Sendo assim, a indústria cultural se fez presença constante na formação do artista, desde a escolha da música para compra do disco e sua audição até a organização de um festival com objetivos comerciais.

Ouvia-se o que estava no cenário global, pois com isso inseria o mundo no cidadão.

E foi isso que aconteceu com os Festivais de Dublagem: o artista que se apresentava ganhava fama e status de artista, era o ícone personificado do artista global, sendo a indústria cultural o instrumento de transformação para a vida musical local, o vetor de mudanças do status e do comportamento do artista, que reproduzia os deuses do rádio e do cinema e, assim, tornavam-se deuses também.

A dublagem, de início, era apenas uma diversão, muitos jovens encontraram na dublagem uma forma de se divertirem nas chamadas "Manhãs de Sol" do clube.

Os dubladores tinham reconhecimento de artista, era glamouroso ser artista, principalmente por imitar e reproduzir os grandes ídolos da 
rádio e do cinema, era ser a estrela ou o pop star personificado em um lugar onde este cantor não estaria e isso era muito representativo.

Uma manifestação musical que fez com que o artista emergisse, possibilitando a emancipação artística posteriormente, não sendo somente um mero reprodutor do que via e ouvia, mas sendo um profissional e reconhecido por seu talento de músico e compositor.

Enfim, ainda temos um cenário muito próximo do que era feito na década de 1960: com outros personagens e outros produtos de consumo da indústria cultural que ainda se faz presente na vida musical da cidade. Mas estas questões são objetos para futuras pesquisas.

\section{Referências}

ADORNO, Theodor W. Indústria Cultural e Sociedade. In LIMA, Luis Costa. Teoria da Cultura de Massas. Rio de janeiro: editora Saga, 1969.

Indústria Cultural e Sociedade. $7^{\text {a }}$ edição. Seleção de textos Jorge Matos Brito de Almeida; traduzido por Julia Elisabeth Levy, [et al.]. São Paulo: Paz e Terra, 2002.

O fetichismo na música e a regressão da audição. In : Textos

Escolhidos. São Paulo: Nova Cultural, 1996. Introdução a Sociologia da Música: doze preleções teóricas.

Tradução Fernando R. de Moraes Barros. São Paulo: Editora Unesp, 2011.

Editora Perspectiva, 1989.

Educação e emancipação. Tradução Wolgang Leo Maar. 3. ed.

Rio de Janeiro: Paz e Terra, 1995.

AGUIAR, José Vicente de Souza. Manaus: praça, café colégio e cinema nos anos 50 e 60. Manaus: Universidade do Amazonas, 2000.

ANDRADE, Mario. Pequena História da Música. 9a edição. Belo Horizonte: Editora Italiana Limitada, 1987.

BARRETO, Jorge Lima. Música e Mass Media. Lisboa: Editora Hugin Lda, 1995.

BATISTA, Djalma. O Complexo da Amazônia: Análise do processo de desenvolvimento. $2^{a}$ edição. Manaus: Editora Valer, 2007.

BENJAMIN, Walter. A obra de arte na época da sua reprodutibilidade técnica. In LIMA, Luis Costa. Teoria da Cultura de Massas. Rio de janeiro: editora Saga, 1969.

BLOOM, Harold. A Angústia da Influência: uma teoria da Poesia. Tradução de Arthur Nestrovski. Rio de Janeiro: Imago, 1991.

BOTELHO, Antonio José. Redesenhando o projeto Zona Franca de Manaus: um estado de alerta (uma década depois). Manaus: Editora Valer, 2006. 
CABRAL, Sérgio. MPB na era do Rádio. São Paulo: Lazuli Editora, 2011.

CALDAS, Waldenyr. Iniciação à Música Popular Brasileira. Barueri, SP: Manole, 2010.

CAMPOS, Augusto de. Balanço da Bossa e outras bossas. $2^{a}$ edição. São Paulo: Editora Perspectiva, 1974.

CARPEUAX, Otto Maria. O Livro de Ouro da História da Música: da Idade Média ao Século XX. $3^{\text {a }}$ edição. Rio de Janeiro: Ediouro, 2001.

CODEAMA - Comissão de Desenvolvimento Econômico do Estado do Amazonas. Estudos Específicos. Ano 1, n.12. Reivindicações. Setor de Publicações. Manaus, dezembro de 1965.

COSTA, Clarice Moura. O despertar para o outro: Musicoterapia. São Paulo: Summus, 1989.

COSTA, Selda Vale; LOBO, Narciso. Hoje tem Guarany. São Paulo: Edição dos Autores, 1983.

DIAS, Marcia Tosta. Os Donos da Voz: indústria fonográfica brasileira e mundialização da cultura. 2 ${ }^{a}$ Ed. São Paulo: Boitempo, 2008.

ELIAS, Norbert. Mozart, Sociologia de um gênio. Organizado por Michael Schröter; Tradução Sergio Goes de Paula. Rio de Janeiro: Jorge Zahar Ed., 1995.

FUBINI, Enrico. Estética da Música. Tradução Sandra Escobar. Lisboa: Biblioteca Nacional de Portugal, Edições 70, 2003.

KAZ, Leonel (Org.); ALBIN, Rocarvo Cravo; HORTA, Luiz Paulo; MAXIMO, João; SOUZA, Tárik;. Brasil, Rito e Ritmo: Um século de Música Popular Clássica. $1^{\mathrm{a}}$ edição. Rio de Janeiro: Editora Aprazível, 2004.

KIEFER, Bruno. História da música brasileira, dos primórdios ao início do século XX. Porto Alegre: Editora Movimento, 1977.

MONTEIRO, Maurício. A construção do gosto: Música e Sociedade na Corte do Rio de Janeiro - 1808-1821. São Paulo: Atelier Editorial, 2008.

MOREIRA, Eidorfe. Amazônia: o conceito e a paisagem. Nova Edição. Rio de Janeiro: Coleção Araújo Lima, Agência SPVEA, 1960.

MORIN, Edgar. Cultura de massas no século XX: o espírito do tempo II NECROSE. Com a colaboração de Irene Nahoum, tradução de Agenor Soares santos. Rio de Janeiro: Forense-Universitária, 1977.

As estrelas: mito e sedução no cinema. Tradução da $3^{\text {a }}$ edição francesa/Luciano trigo. Rio de Janeiro: José Olympio, 1989.

NOGUEIRA, Luiz Eugênio Negreiros. O Rádio no País das Amazonas. Manaus: Editora Valer, 1999.

OLIVEIRA, José Aldemir. Manaus de 1920 -1967: a cidade doce e dura em excesso. Manaus: Editora Valer, Governo do Estado do Amazonas, Editora da Universidade Federal do Amazonas, 2003.

PIGNATARI, Decio. Letras, artes e mídia. São Paulo: Editora Globo, 1995.

RAYNOR, Henry. História Social da Música: Da Idade Média a Beethoven. Tradução Nathanael C. Caixeiro. Rio de Janeiro: Zahar Editores, 1981.

REIS, Arthur Cesar Ferreira. A Amazônia e a integridade do Brasil. Série Alberto Torres. Impressos nos Estados Unidos do Brasil. Manaus: Edições Governo do Estado do Amazonas, 1966.

SANTOS, Milton. A Natureza do espaço: técnica e tempo, razão e emoção. $3^{\text {a }}$ edição. São Paulo: Hucitec, 1999. 
Por uma outra globalização: do pensamento único à consciência universal. $6^{a}$ edição. Rio de Janeiro: Record, 2001.

SEREN, Lucas. Gosto, música e juventude. São Paulo: Annablume, 2011.

SODRÉ, Nelson Werneck. Síntese de História da Cultura Brasileira. $12^{\text {a }}$ Edição. São Paulo: DIFEL, 1984.

TINHORÃO, José Ramos. Música Popular: um tema em debate. $3^{\text {a }}$ Edição revista e ampliada. São Paulo: Ed. 74, 1997.

1998. História Social da Música Popular Brasileira. São Paulo: Ed. 74,

AUDIOVISUAIS

LILI ANDRADE. Sons e Canções. Manaus, TV Ufam, 22 jul.2009. Programa de Tv. KATIA MARIA. Sons e Canções. Manaus, TV Ufam, 27 nov.2009. Programa de TV.

\section{Entrevistas}

ANTONIO, Fernando. O comércio cultural em Manaus. Manaus, 30 mar. 2012. Registro sobre o comércio, a Lojas e a divulgação de discos. Entrevista concedida a Lucyanne de Melo Afonso.

BENAION, Noval. Música popular em Manaus. Manaus, UFAM, 14 jul. 2011. Registro sobre o cenário musical em Manaus na década de 1960. Entrevista concedida a Lucyanne de Melo Afonso.

MARINHO, Joaquim. O rádio e a televisão na difusão da música popular em Manaus. Manaus, UFAM, 06 jul. 2011 . Registro sobre os meios de comunicação e o cenário musical em Manaus na década de 1960. Entrevista concedida a Lucyanne de Melo Afonso.

SÁ, Delfim de. Festival de Dublagem e a indústria cultural. Manaus, UFAM, 30 mar. 2012. Registro sobre o cenário musical em Manaus na década de 1960. Entrevista concedida a Lucyanne de Melo Afonso.

SANTOS, Maria Jerusalém dos. O rádio em Manaus na década de 1960. Manaus, UFAM, 06 nov. 2012. Registro sobre o cenário musical em Manaus na década de 1960. Entrevista concedida a Lucyanne de Melo Afonso.

SANTOS, Adelson. Música popular em Manaus. Manaus, UFAM, 12 jul. 2011. Registro sobre o cenário musical em Manaus na década de 1960. Entrevista concedida a Lucyanne de Melo Afonso.

SAHADO, Edinelza. Os festivais de Dublagem. Manaus, UFAM, 22 nov. 2011. Registro sobre os festivais de dublagem e as festas $\mathrm{Hi}-\mathrm{Fi}$ na década de 1960. Entrevista concedida a Lucyanne de Melo Afonso.

VIEIRA, Jurandir. O Rádio e a Música em Manaus de 1960. Manaus, 03 dez. 2011. Registro sobre os meios de comunicação, os programas de rádio e a censura. Entrevista concedida a Lucyanne de Melo Afonso. 